\title{
Pengaruh Persepsi, Pengetahuan Akuntansi, dan Penghargaan Finansial Terhadap Minat Mahasiswa Program Studi Akuntansi Untuk Berkarir di Bidang Akuntan Publik
}

\author{
*Dika Ayu Puspitasari, Tri Lestari, Nur Lailiyatul Inayah \\ Program Studi Akuntansi Fakultas Ekonomi dan Bisnis \\ Universitas Bhayangkara Surabaya, Indonesia
}

DOI: 10.46821/ekobis.v1i2.31

\begin{abstract}
ABSTRAK
Penelitian ini dilatarbelakangi berdasarkan fenomena yang ada menunjukkan jumlah akuntan publik di Indonesia masih tidak seimbang dengan jumlah penduduk yang ada di Indonesia. Penelitian ini bertujuan untuk mengetahui Pengaruh Persepsi, Pengetahuan Akuntansi, dan Penghargaan Finansial terhadap Minat Mahasiswa Program Studi Akuntansi untuk Berkarir di Bidang Akuntan Publik. Penelitian ini menggunakan teknik analisis pendekatan kuantitatif. Jenis data yang digunakan dalam penelitian ini adalah data sekunder yang berasal dari hasil penyebaran kuisioner dengan populasi sebanyak 140 Responden. Hasil penelitian ini menunjukkan bahwa Pengaruh Persepsi (X1), Pengetahuan Akuntansi (X2) dan Penghargaan Finansial (X3) secara parsial berpengaruh positif terhadap Minat Berkarir di Bidang Akuntan Publik (Y).
\end{abstract}

Kata kunci : Persepsi, Pengetahuan Akuntansi, Penghargaan Finansial, Minat Berkarir di Bidang Akuntan Publik.

\begin{abstract}
This research is based on existing phenomena showing that the number of public accountants in Indonesia is still out of balance with the population in Indonesia. This study aims to determine the effect of perception, accounting knowledge, and financial rewards on the interests of students in the Accounting Study Program for a Career in the field of public accounting. This research uses a quantitative approach analysis technique. The type of data used in this study is secondary data derived from the distribution of questionnaires with a population of 140 respondents. The results of this study indicate that the Effect of Perception (X1), Accounting Knowledge (X2) and Financial Awards (X3) partially has a positive effect on Career Interest in the Field of Public Accountants (Y).
\end{abstract}

Keywords: Perception, Accounting Knowledge, Financial Awards, Career Interests in the Field of Public Accountants.

\section{PENDAHULUAN}

Karir merupakan suatu proses pembelajaran dan peran kesempatan dalam perjalanan kehidupan individu untuk meningkatkan taraf hidup. Dengan demikian setiap individu berusaha memperoleh kehidupan yang layak secara ekonomis. Menurut Rivai dan Sagala (2016:266), karir adalah seluruh pekerjaan yang dimiliki atau dilakukan oleh individu selama masa hidupnya. Berdasarkan 
berbagai definisi di atas dapat disimpulkan bahwa karir adalah rangkaian urutan posisi pekerjaan yang dipegang seseorang dalam riwayat hidup pekerjaannya.

Akuntan di Indonesia berada dalam sebuah organisasi profesi yang disebut Ikatan Akuntan Indonesia (IAI). IAI berdiri pada tahun 1957 dan beranggotakan akuntan dari berbagai bidang yang terbagi dalam 4 (empat) komponen, yaitu akuntan public (Auditor), akuntan manajemen, akuntan pemerintahan dan akuntan pendidik. Sampai saat ini profesi akuntan publik terus mengalami perkembangan,akan tetapi hingga sekarang di Indonesia masih sangat kekurangan akuntan public (Auditor). Hal ini dapat disebabkan salah satunya karena kurangnya minat mahasiswa yang telah lulus sarjana untuk berprofesi sebagai akuntan publik.

Minat adalah keinginan seseorang terhadap sesuatu. Jika seseorang yang mempunyai minat terhadap suatu objek, maka akan cenderung memberikan perhatian lebih besar atau merasa senang kepada objek tersebut. Minat juga dapat menjadi penyebab dari kegiatan dan partisipasi. Ketertarikan pada seseorang atau suatu objek tidak akan tiba-tiba muncul pada individu tersebut. Ketertarikan dapat muncul pada manusia melalui suatu proses. Minat ini dapat berkembang melalui perhatian dan interaksi dengan lingkungan. Dapat disimpulkan bahwa seseorang yang berminat terhadap suatu aktivitas akan memperhatikan aktivitas itu secara konsisten dengan rasa senang dikarenakan hal tersebut datang dari dalam diri seseorang yang didasarkan rasa suka dan tidak adanya paksaan dari pihak luar. Namun seperti yang diketahui minat berprofesi sebagai akuntan publik (auditor) pada mahasiswa akuntansi masih rendah.

Paramita dkk. (2019), meneliti Pengaruh Persepsi Mengenai Profesi Akuntan Publik, Motivasi, dan Kecerdasan Adversity Terhadap Minat Menjadi Akuntan Publik. Penelitian tersebut dilakukan terhadap mahasiswa di Universitas Udayana Bali. Dari hasil penelitian diketahui bahwa dalam memilih suatu karir, mahasiswa harus mayakinkan dengan cara memotivasi diri dan memiliki kecerdasan adversity yang berpengaruh terhadap minat menjadi Akuntan Publik. Dibabe et al.,(2015), menemukan peluang pekerjaan berpengaruh signifikan positif pada pilihan karir mahasiswa akuntansi. Pertimbangan pasar kerja meliputi keamanan kerja dan tersedianya lapangan kerja atau kemudahan mengakses lowongan kerja. Berdasarkan hasil penelitian yang dilakukan oleh (Naminingsih, 2018) Pelatihan profesional berpengaruh signifikan terhadap pemilihan karir Akuntan Publik. Hal ini mengartikan mahasiswa bahwa suatu organisasi yang baik akan memberikan suatu pembekalan dan peningkatan keahlian melalui pelatihan professional yang diberikan untuk calon karyawan ataupun karyawan tetap merupakan, serta hal tersebut pastinya akan memberikan dampak secara signifikan bagi karyawan serta calon karyawan. Profesi yang memiliki pelatihan professional yang baik akan menjadi suatu daya tarik bagi profesi tersebut. (Danu Pradana, 2017) Motivasi pada Minat untuk berprofesi sebagai Akuntan Perusahaan perlu ditingkatkan. Hal tersebut dapat dilihat dari masih adanya beberapa mahasiswa yang memiliki motivasi yang rendah ataupun kurang berminat untuk berprofesi sebagai Akuntan Perusahaan.

Penghargaan finansial atau gaji adalah sebuah penghargaan yang berwujud finansial. Suparyadi (2015:271) menyatakan bahwa kompensasi merupakan keseluruhan imbalan yang diterima oleh karyawan sebagai penghargaan atas kontribusi yang diberikan kepada organisasi, baik yang bersifat finansial maupun 
non finansial." (Malayu Hasibuan 2016:118) Kompensasi adalah semua pendapatan yang berbentuk uang, barang langsung atau tidak langsung yang diterima karyawan sebagai imbalan atas jasa yang diberikan kepada perusahaan. Penghargaan finansial/ gaji dipandang sebagai alat ukur untuk menilai pertimbangan jasa yang telah diberikan karyawan sebagai imbalan yang telah diperolehnya. Penghargaan finansial/gaji adalah reward dalam bentuk nilai mata uang yang biasanya diberikan sebagai bentuk timbal balik atas pemberian jasa, tenaga, usaha dan manfaat seseorang dalam suatu ikatan pekerjaan. Kompensasi adalah merupakan balas jasa yang diberikan oleh perusahaan kepada karyawannya sebagai pengganti kontribusi jasa mereka pada perusahaan. (Nitisemito 2018:149).

\section{TINJAUAN PUSTAKA}

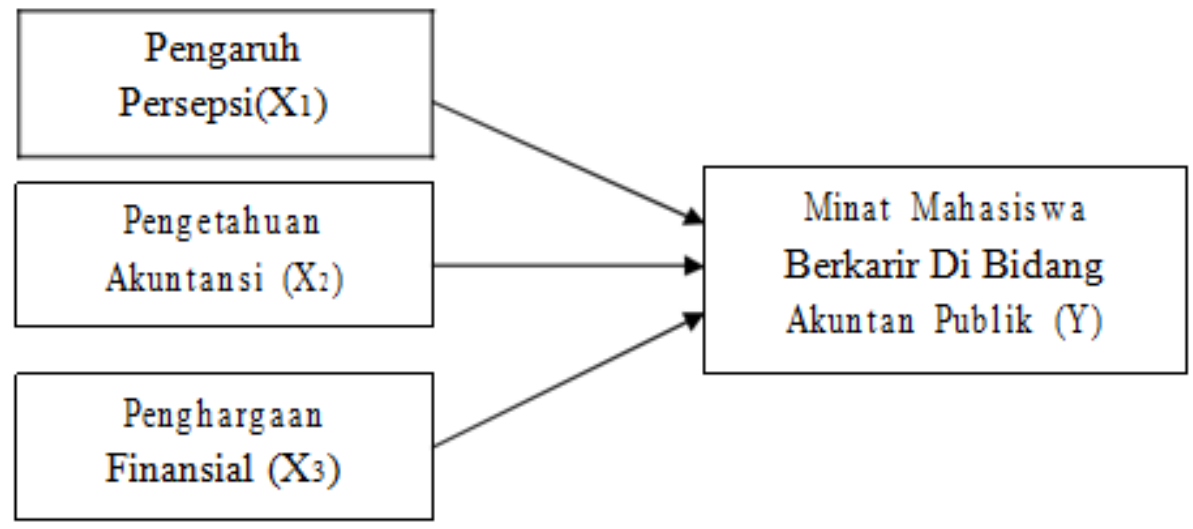

\section{Gambar 1 \\ Kerangka Konseptual}

\section{Hipotesis :}

a. Bahwa Variabel Pengaruh Persepsi (X1) berpengaruh signifikan terhadap Minat Mahasiswa Berkarir di Bidang Akuntan Publik (Y).

b. Bahwa Variabel Pengetahuan Akuntansi (X2) berpengaruh signifikan terhadap Minat Mahasiswa Berkarir Di Bidang Akuntan Publik (Y).

c. Bahwa Hubungan Penghargaan Finansial (X3) berpengaruh signifikan terhadap Minat Mahasiswa Berkarir di Bidang Akuntan Publik (Y).

\section{METODE PENELITIAN \\ Definisi Operasional Variabel \\ Persepsi $\left(\mathbf{X}_{1}\right)$}

Stephen P.Robbins (2017:103) Persepsi adalah sebuah proses individu mengorganisasikan dan menginterpretasikan kesan sensoris untuk memberikan pengertian pada lingkungannya. Adapun pengertian lain persepsi menurut Gibson Ivancevich Donnatelly (2017:56) adalah proses kognitif yang dipergunakan oleh seseorang untuk menafsirkan dan memahami dunia sekitarnya dengan melibatkan pengaturan dan penginterprestasian berbagai macam stimuli (rangsangan) ke dalam sebuah pengalaman psikologis.

\section{Pengetahuan Akuntansi $\left(\mathbf{X}_{2}\right)$}

Akuntansi berasal dari kata asing yaitu accounting, yang artinya bila diterjemahkan adalah menghitung atau mempertanggungjawabkan. Menurut Al- 
Haryono Jusup (2018:4-5) pengertian akuntansi dapat dirumuskan dari dua sudut pandang, yaitu dari sudut pemakai jasa akuntansi dan dari sudut proses kegiatannya. Dari sudut pemakai: Akuntansi adalah suatu disiplin yang menyediakan informasi yang diperlukan untuk melaksanakan kegiatan secara efisien dan mengevaluasi kegiatan-kegiatan suatu organisasi. Dari sudut proses kegiatan: Akuntansi adalah proses pencatatan, penggolongan, peringkasan, pelaporan, dan penganalisisan data keuangan suatu organisasi.

\section{Penghargaan Finansial / Kompensasi $\left(\mathbf{X}_{3}\right)$}

Menurut Hasibuan (2016:118) Kompensasi adalah semua pendapatan yang berbentuk uang, barang langsung atau tidak langsung yang diterima karyawan sebagai imbalan atas jasa yang diberikan kepada perusahaan. Adapun indikator yang digunakan untuk mengukur Kompensasi menurut Simamora dalam Heriyati(2016) sebagai berikut:
a. Gaji/Upah
b. Insentif
c. Tunjangan
d. Fasilitas

\section{Minat Mahasiswa Berkarir Menjadi Akuntan Publik (Y)}

UU No. 5 tahun 2011 yang menyatakan bahwa, para sarjana non akuntansi dapat berprofesi sebagai akuntan publik asalkan lulus ujian sertifikasi. Hal tersebut berarti bahwa dapat mengancam para lulusan jurusan akuntansi, dimana untuk menjadi akuntan publik mereka para lulusan dari jurusan akuntansi harus bersaing dengan lulusan dari jurusan non akuntansi. Hal ini disebabakan karena pertumbuhan akuntan di indonesia sangat lambat. Sampai dengan saat ini indonesia sangat kekurangan tenaga profesional akuntan publik. Jumlah wajib audit yang ada di Indonesia seiring makin meningkatnya ekonomi dan munculnya perusahaan-perusahaan atau lembaga baru serta makin berkembangnya perusahaan/lembaga yang sudah ada. Hal ini sangat tidak sebanding dengan jumlah akuntan publik yang ada. Padahal akuntan publik sangat berperan penting dan strategis bagi perusahaan swasta dan lembaga publik lainnya. Akuntan Publik sangat menentukan kualitas laporan keuangan yang akan berkontribusi pada penetapan kebijakan-kebijakan keuangan yang pada akhirnya dapat berpengaruh pada perekonomian negara.

\section{Sumber Data, Populasi, Sampel, dan Teknik Pengambilan Sampel}

Jenis data yang digunakan dalam penelitian ini adalah data Kuantitatif. Populasi dalam hal ini dipergunakan adalah Mahasiswa dan Mahasiswi Universitas Bhayangkara Surabaya Fakultas Ekonomi dan Bisnis Jurusan Akuntansi Tahun Angkatan 2016 yang sudah menjalani mata kuliah auditing I,II dan sedang menjalani proses skripsi (tugas akhir) yang berjumlah 214 orang. Teknik sampel yang akan digunakan dalam penelitian ini adalah Non Probability Sampling dengan menggunakan Sampling Jenuh. Sampel dari penelitian ini adalah 140 mahasiswa. 


\section{Teknik Analisis Data}

Teknik analisis data yang digunakan dalam penelitian ini dilakukan dengan menggunakan analisis regresi linier berganda.

\section{HASIL ANALISIS DAN PEMBAHASAN}

\section{Analisis Regresi Linier Berganda}

Dari Lampiran 1, dapat diketahui bahwa persamaan regresi yang dihasilkan adalah sebagai berikut: Rumus regresi yang digunakan adalah:

$$
\begin{aligned}
& \mathrm{Y}=\alpha+\beta 1 \mathrm{X} 1+\beta 2 \mathrm{X} 2+\beta 3 \mathrm{X3}+\mathrm{e} \\
& \mathrm{Y}=-4,751+0.526 \mathrm{X} 1+0.444 \mathrm{X} 2+0.391 \mathrm{X} 3+\mathrm{e}
\end{aligned}
$$

Keterangan:

$$
\begin{array}{ll}
\mathrm{Y} & =\text { Berkarir di Bidang Akuntan Publik } \\
\mathrm{X} 1 & =\text { Pengaruh Persepsi } \\
\mathrm{X} 2 & =\text { Pengetahuan Akuntansi } \\
\mathrm{X} 3 & =\text { Penghargaan Finansial } \\
\beta & =\text { Koefisien Regresi } \\
\mathrm{e} & =\text { Residual error }
\end{array}
$$

Berdasarkan analisa nilai koefisien regresi tersebut maka dapat disimpulkan bahwa :

1. Nilai variabel dependen Berkarir di Bidang Akuntan Publik (Y). dapat dilihat dari nilai konstantanya sebesar -4.331 dengan catatan variabel independen tetap.

2. Pengaruh variabel independen Pengaruh Persepsi (X1) terhadap Berkarir di Bidang Akuntan Publik (Y) apabila dilihat dari besarnya koefisien regresi 0.464 maka dapat diartikan bahwa setiap perubahan Pengaruh Persepsi (X1) sebesar satu satuan maka variabel Berkarir di Bidang Akuntan Publik (Y) akan meningkat sebesar sebesar 0.464 dengan catatan variabel independen lainnya tetap.

3. Pengaruh variabel independen Pengetahuan Akuntansi (X2) terhadap Berkarir di Bidang Akuntan Publik (Y) apabila dilihat dari besarnya koefisien regresi 0.496 maka dapat diartikan bahwa setiap perubahan variabel Pengetahuan Akuntansi (X2) sebesar satu satuan maka variabel Berkarir di Bidang Akuntan Publik (Y) akan meningkat sebesar 0,496 catatan variabel independen lainnya tetap.

4. Pengaruh variabel independen Penghargaan Finansial (X3) terhadap Berkarir di Bidang Akuntan Publik (Y) apabila dilihat dari besarnya koefisien regresi 0.376 maka dapat diartikan bahwa setiap perubahan variabel Penghargaan Finansial (X3) sebesar satu satuan maka variabel Berkarir di Bidang Akuntan Publik (Y) akan meningkat sebesar sebesar 0,376 catatan variabel independen lainnya tetap.

\section{Uji Hipotesis}

Dari Lampiran 2, dapat diketahui bahwa uji t (parsial) ditunjukkan nilai Sig. sebesar 0,000 yang berarti Pengaruh Persepsi (X1) secara parsial berpengaruh positif terhadap Berkarir di Bidang Akuntan Publik (Y), Pengetahuan Akuntansi (X2) secara parsial berpengaruh positif terhadap Berkarir di Bidang Akuntan 
Publik (Y) dan Penghargaan Finansial (X3) secara parsial berpengaruh positif terhadap Berkarir di Bidang Akuntan Publik (Y).

\section{Pembahasan \\ Pengaruh Persepsi secara parsial Terhadap Minat Mahasiswa Program Studi Akuntansi Untuk Berkarir di Bidang Akuntan Publik}

Hasil penelitian pada hipotesis pertama dalam penelitian ini yang menyatakan bahwa Pengaruh Persepsi (X1) berpengaruh signifikan terhadap Minat Mahasiswa Program Studi Akuntansi untuk Berkarir Di Bidang Akuntan Publik. . Variabel Pengaruh Persepsi dalam penelitian ini memiliki nilai t hitung 8,827. Hasil olah data yang dilakukan memiliki nilai probabilitas signifikasi sebesar 0.000 dimana nilai tersebut lebih kecil dari 0.05 . Hipotesis pertama dalam penelitian ini yang menyatakan Pengaruh Persepsi berpengaruh terhadap Minat Mahasiswa Program Studi Akuntansi Untuk Berkarir di Bidang Akuntan Publik. Jadi, dapat disimpulkan hipotesis pertama pada penelitian ini tidak ditolak. Hasil penelitian konsisten dengan hasil penelitian Novia Nurul Aini (2017) yang menyatakan bahwa Pengaruh Persepsi memiliki pengaruh positif dan signifikan terhadap Minat Mahasiswa Berkarir di Bidang Akuntan Publik. Hasil tersebut membuktikan bahwa pengaruh persepsi adalah salah satu faktor yang mempengaruhi minat pemilihan profesi berkarir di bidang akuntan publik.

\section{Pengetahuan Akuntansi Terhadap Minat Mahasiswa Program Studi Akuntansi Untuk Berkarir di Akuntansi Publik}

Hasil penelitian pada hipotesis kedua dalam penelitian ini yang menyatakan bahwa Pengetahuan Akuntansi (X2) berpengaruh signifikan terhadap Minat Mahasiswa Program Studi Akuntansi untuk Berkarir Di Bidang Akuntan Publik. Variabel Pengetahuan Akuntansi dalam penelitian ini memiliki nilai t hitung 6.443. Hasil olah data yang dilakukan memiliki nilai probabilitas signifikasi sebesar 0.000 dimana nilai tersebut lebih kecil dari 0.05. Hipotesis dalam penelitian ini yang menyatakan Pengetahuan Akuntansi berpengaruh terhadap Minat Mahasiswa Program Studi Akuntansi Untuk Berkarir di Bidang Akuntan Publik. Jadi, dapat disimpulkan hipotesis kedua pada penelitian ini tidak ditolak. Hasil penelitian konsisten dengan hasil penelitian Sri Mulyati (2018) yang menyatakan bahwa Pengetahuan Akuntansi memiliki pengaruh secara signifikan terhadap Minat Mahasiswa Program Studi Akuntansi Untuk Berkarir di Bidang Akuntan Publik. Hasil tersebut membuktikan bahwa pengetahuan akuntansi adalah salah satu faktor penting terhadap Minat Mahasiswa Berkarir di Bidang Akuntan Publik.

\section{Penghargaan Finansial Terhadap Minat Mahasiswa Program Studi Akuntansi Untuk Berkarir di Akuntansi Publik}

Hasil penelitian pada hipotesis ketiga dalam penelitian ini yang menyatakan bahwa Penghargaan Finansial (X3) berpengaruh positif terhadap Minat Mahasiswa Program Studi Akuntansi untuk Berkarir Di Bidang Akuntan Publik. Hasil olah data yang dilakukan menunjukkan hasil signifikasi sebesar 0.001 lebih kecil dari 0.05. Hipotesis Penghargaan Finansial berpengaruh terhadap Minat Mahasiswa Program Studi Akuntansi Untuk Berkarir di Bidang Akuntan Publik. Jadi, dapat disimpulkan hipotesis ketiga pada penelitian ini tidak ditolak. Namun hasil penelitian ini tidak konsisten dengan penelitian dari Nana Naraika(2017) 
yang menyebutkan bahwa penghargaan finansial tidak berpengaruh dengan Minat Mahasiswa Program Studi Akuntansi untuk Berkarir di Bidang Akuntan Publik.

\section{SIMPULAN}

Berdasarkan hasil olah data serta pembahasan pada bab sebelumnya maka dapat ditarik kesimpulan bahwa: 1. Variabel Pengaruh Persepsi secara parsial berpengaruh secara signifikan terhadap Berkarir di Bidang Akuntan Publik. 2. Pengetahuan Akuntansi secara parsial berpengaruh positif terhadap Berkarir di Bidang Akuntan Publik. 3. Penghargaan Finansial secara parsial berpengaruh positif terhadap Berkarir di Bidang Akuntan Publik. 4. Pengaruh Persepsi (X1) memiliki pengaruh paling dominan terhadap Berkarir di Bidang Akuntan Publik (Y). 5. 85,3\% Berkarir di Bidang Akuntan Publik (Y) dipengaruhi oleh Pengaruh Persepsi (X1), Pengetahuan Akuntansi (X2), Penghargaan Finansial (X3) serta sisanya $14,7 \%$ dipengaruhi oleh variabel lain diluar penelitian. Terdapat beberapa saran yang patut dipertimbangan untuk penelitian berikutnya antara lain : 1. Bagi Fakultas Ekonomi dan Bisnis Terutama Jurusan Akuntansi. Sosialisasi kepada mahasiswa mengenai pentingnya peran akuntan publik. Tambahan keterampilan atau keprofesionalitas skill oleh IAPI serta akuntan pendidik sebagai penyelia ilmu untuk meningkatkan kompetensi yang bersetifikat sebagai syarat kelulusan (SKPI) sehingga mahasiswa merasa mampu untuk mengikuti dan mampu menghadapi persaingan kemajuan teknologi. Hasil penelitian ini dapat menjadi masukan upaya pengajaran auditing agar lebih detail terhadap akuntan publik. Misalnya dalam pengajaran auditing dilakukannya praktek di lapangan seperti Kantor Akuntan Publik, sehingga mahasiswa bisa mengetahui dan belajar secara langsung dengan pekerjaan seorang akuntan publik. Bagi peneliti selanjutnya Diharapkan untuk peneliti selanjutnya hendaknya mengulas lebih luas dan mendalam mengenai variabel yang berhubungan dengan akuntan publik.

\section{DAFTAR PUSTAKA}

Alex S. Nitisemito. 2018. Manajemen Personalia. Jakarta. Ghalia Indonesia.

Ambari dan Ramantha. (2017). Pertimbangan Pasar Kerja, Pengakuan Profesional, Nilai-Nilai Sosial, Lingkungan Kerja, Personalitas Pemilihan Karir Sebagai Akuntan Publik. E-Jurnal Akuntansi Universitas Udayana, 18, 705-734.

Badriyah, Mila. 2015. Manajemen Sumber Daya Manusia. Bandung. Pustaka Setia

Denziana, Angrita. (2017). Pengaruh Motivasi, Persepsi Biaya Pendidikan Dan Lama Pendidikan Terhadap Minat Mahasiswa Akuntansi Untuk Mengikuti Pendidikan Profesi Akuntansi (Ppak) (Studi Kasus Pada Perguruan Tinggi Di Bandar Lampung) Jurnal Akuntansi dan Keuangan Volume 8, No. 2, September 2017.

Ghozali, Imam. 2006. Aplikasi Analisis Multivariate Dengan Program SPSS, Semarang : Badan Penerbit Diponegoro 
Gibson \& Ivancevich \& Donelly. 2015. Organisasi Dalam Menagemen: Perilaku Struktur. Jakarta. Erlangga.Harianti, S S. 2017. Pengaruh Penghargaan Finansial, Pertimbangan Pasar Kerja dan Lingkungan Keluarga terhadap Minat menjadi Akuntan Publik. Skripsi. Univeristas Negeri Padang.

Hasibuan, Malayu S. P. 2019. Manajemen Sumber Daya Manusia. Edisi Revisi. Jakarta: Bumi Aksara.

Kartikahadi, Hans, dkk. 2016. Akuntansi Keuangan Berdasarkan SAK Berbasis IFRS. Jakarta: IAI.

Kieso, Donald E., Jerry J. Weygandt., \& Terry D. Warfield. 2016. Intermediate Accounting IFRS Edition. Volume Pertama. United States of America: John Wiley \& Sons.

Institut Akuntansi Publik Indonesia. 2016. Standar Profesional Akuntan Publik. Jakarta: Salemba Empat.

Institut Akuntansi Publik Indonesia. 2016. Undang-Undang Republik Indonesia No. 5 Tahun 2011 tentang Akuntan Publik. Jakarta: Salemba Empat.

Lukman, Hendro. 2015. Pengaruh Nilai Intrisik, Gender, Parental influence, persepsi mahasiswa dan pertimbangan pasar kerja dengan pendekatan Theory Of Reasoned Action Model terhadap pemilihan karir sebagai akuntan publik bagi Mahasiswa Perguruan Tinggi Swasta di Jakarta. Proceding Simposium Nasional Akuntansi 18 Medan.

Mulyadi. 2015. Auditing Buku 1 edisi 6 . Jakarta: Salemba Empat.

Mulyadi. 2015. Sistem Akuntansi. Jakarta: Salemba Empat.

Naminingsih, N. N. 2018. Pengaruh Penghargaan Finansial, Pelatihan Profesional, Pengakuan Profesional, Pertimbangan Pasar, Teman dan Keluarga dalam pemilihan karir Akuntan Publik.

Novia, Nurulaini. 2017. Pengaruh Persepsi Mahasiswa Mengenai Pertimbangan Pasar Kerja Profesi Akuntan Publik, Penghargaan Finansial Profesi Akuntan Publik, Dan Risiko Profesi Akuntan Publik Terhadap Minat Mahasiswa Program Studi Akuntansi Universitas Negeri Yogyakarta Untuk Berkarier Menjadi Akuntan Publik.

PPA FE-UI. 2020. "Certified Public Accountant (CPA) Review Level Profesional". Diambil dari : https://ppa-feui.com/certified-public accountant-cpa-review-kurikulum-baru/, pada tanggal 02 Maret 2020.

Pradana, Danu. 2017. Pengaruh Motivasi Dan Persepsi Mahasiswa Tentang Pendidikan Profesi Akuntansi Terhadap Minat Menjadi Akuntan Perusahaan Pada Mahasiswa Akuntansi Fakultas Ekonomi Universitas Negeri Yogyakarta.

Robbin, Stephen P. 2017. Perilaku Organisasi. Edisi 16. Jakarta. Salemba Empat 
Ramadhan, Azhari Ramadhan. 2018. Pengaruh Literasi Keuangan dan Akses Permodalan Terhadap Kinerja Keuangan UMKM di Kota Bandung. Skripsi. Universitas Pasundan: tidak diterbitkan.

R Antares. (2019). Jumlah Akuntan Indonesia Masih Minim di Tingkat ASEAN. Tagar News. Retrieved from https://www.tagar.id/jumlah-akuntanindonesia-masih-minim-di-tingkat- asean.

Suparyadi. 2015. Managemen Sumber Daya Manusia, Menciptakan Keunggulan Bersaing Berbasis Kompetisi SDM. Jakarta: Andi.

Sugiyono. 2016. Metode Penelitian Kuantitatif Kualitatif Dan R\&D. Bandung: Alfabeta.

Suwardjono. 2015. Teori Akuntansi (Perekayasaan Pelaporan Keuangan) Edisi Ketiga. Yogyakarta: BPFE.

Tandiontong Mathius. 2016. Kualitas Audit dan Pengukurannya. Cetakan Kesatu. CV. Alfabeta. Bandung

Yuliana Paramita, Putu Vicky. 2019. Pengaruh Persepsi Mengenai Profesi Akuntan Publik, Motivasi, dan Kecerdasan Adversity Terhadap Minat Menjadi Akuntan Publik. E-Jurnal Akuntansi Universitas Udayana Vol.26.1.Januari (2019).

Zaid, Muhammad Ikhwan. 2015. Pengaruh Gender, Penghargaan Finansial, dan Pertimbangan Pasar Kerja terhadap Minat Mahasiswa Akuntansi untuk Berkarir Menjadi Akuntan Publik. Universitas Negeri Yogyakarta. Jurnal Ilmiah Mahasiswa Akuntansi. 
Ekobis: Jurnal Ekonomi \& Bisnis

Vol. 1 No. 22020
Dika A Puspitasari dkk., Minat Mahasiswa Berkarir di Bidang Akuntan Publik

\section{Lampiran 1. Analisis Regresi Linier Berganda \\ Coefficients}

\begin{tabular}{|c|c|c|c|c|c|c|c|}
\hline \multirow[b]{2}{*}{ Model } & \multicolumn{2}{|c|}{$\begin{array}{l}\text { Unstandardized } \\
\text { Coefficients }\end{array}$} & \multirow{2}{*}{$\begin{array}{c}\begin{array}{c}\text { Standardized } \\
\text { Coefficients }\end{array} \\
\text { Beta }\end{array}$} & \multirow[b]{2}{*}{$\mathrm{t}$} & \multirow[b]{2}{*}{ Sig. } & \multicolumn{2}{|c|}{$\begin{array}{l}\text { Collinearity } \\
\text { Statistics }\end{array}$} \\
\hline & B & Std. Error & & & & Tolerance & VIF \\
\hline 1 (Constant) & -4.311 & 1.070 & & -4.028 & .000 & & \\
\hline $\begin{array}{l}\text { Pengaruh } \\
\text { Persepsi(X1) }\end{array}$ & .464 & .053 & .436 & 8.827 & .000 & .820 & 1.219 \\
\hline $\begin{array}{l}\text { Pengetahuan } \\
\text { Akuntansi } \\
\text { (X2) }\end{array}$ & .496 & .077 & .346 & 6.443 & .000 & .696 & 1.436 \\
\hline $\begin{array}{l}\text { Penghargaan } \\
\text { Finansial (X3) }\end{array}$ & .376 & .062 & .318 & 6.107 & .000 & .740 & 1.352 \\
\hline
\end{tabular}

a. Dependent Variable: Berkarir Di Bidang Akuntan Publik (Y)

Sumber: Data Diolah, 2020

\section{Lampiran 2. Hasil Uji t (Parsial)}

Coefficients $^{2}$

\begin{tabular}{|c|c|c|c|c|c|c|c|}
\hline \multirow[b]{2}{*}{ Model } & \multicolumn{2}{|c|}{$\begin{array}{l}\text { Unstandardized } \\
\text { Coefficients }\end{array}$} & \multirow{2}{*}{$\begin{array}{c}\begin{array}{c}\text { Standardized } \\
\text { Coefficients }\end{array} \\
\text { Beta }\end{array}$} & \multirow[b]{2}{*}{$t$} & \multirow[b]{2}{*}{ Sig. } & \multicolumn{2}{|c|}{$\begin{array}{l}\text { Collinearity } \\
\text { Statistics }\end{array}$} \\
\hline & B & Std. Error & & & & Tolerance & VIF \\
\hline 1 (Constant) & -4.311 & 1.070 & & -4.028 & .000 & & \\
\hline $\begin{array}{l}\text { Pengaruh } \\
\text { Persepsi(X1) }\end{array}$ & .464 & .053 & .436 & 8.827 & .000 & .820 & 1.219 \\
\hline $\begin{array}{l}\text { Pengetahuan } \\
\text { Akuntansi } \\
\text { (X2) }\end{array}$ & .496 & .077 & .346 & 6.443 & .000 & .696 & 1.436 \\
\hline $\begin{array}{l}\text { Penghargaan } \\
\text { Finansial (X3) }\end{array}$ & .376 & .062 & .318 & 6.107 & .000 & .740 & 1.352 \\
\hline
\end{tabular}

a. Dependent Variable: Berkarir Di Bidang Akuntan Publik (Y)

Sumber: Data Diolah, 2020 